Magdalena Anna Owczarekl, Tadeusz Kałużewski ${ }^{1}$, Dorota Kucharska ${ }^{l}$, Michat Bednarekl, Agnieszka Morel ${ }^{1}$, Adam Jędrzejczyk², Bogdan Katużewski ${ }^{1}$

\title{
COMPARATIVE ANALYSIS OF 13 HPV GENOTYPES DIAGNOSED IN URINE SEDIMENT CELLS VS. DESQUAMATED CERVICAL EPITHELIAL CELLS
}

\section{ANALIZA PORÓWNAWCZA 13 GENOTYPÓW HPV ZDIAGNOZOWANYCH W KOMÓRKACH OSADU MOCZU W ODNIESIENIU DO ZŁUSZCZONYCH KOMÓREK NABŁONKOWYCH SZYJKI MACICY}

${ }^{1}$ Laboratory of Medical Genetics of the "Genos" Partnership R\&D Division, Member of the Polish Technological Platform of Innovative Medicine of the National Centre of Research \& Development.

${ }^{2}$ Department of Urology, the JP II Voividship Hospital in Belchatow, Czapliniecka st. 123, 97-400 Belchatow, Poland

${ }^{1}$ Laboratorium Genetyki Medycznej „Genos” s.c. Dział R\&D - Członek Polskiej Platformy Technologicznej Innowacyjnej Medycyny Narodowego Centrum Badań i Rozwoju

${ }^{2}$ Szpital Wojewódzki im. Jana Pawła II w Bełchatowie - Oddział Urologiczny

\begin{abstract}
INTRODUCTION. The human papilloma virus (HPV) belongs to double-stranded, DNA circular viruses which infect the epithelial cells. The highest incidence of HPV is identified in malignant processes which affect the uterine cervix, as well as vulvar, penile, rectal and pharyngeal regions.

GOAL OF STUDY. An attempt to find correlations between HPV incidence rates in urine sediment cells and in desquamated epithelial cells of the uterine cervix in a group of patients with frequent, recurrent cystitis.

MATERIALS AND METHODS. HPV presence was studied, both in urine sediment cells and in uterine cervix epithelial cells of 77 patients.

RESULTS. An analysis of urinary sediments brought a total of twenty (25.97\%) positive and 57 (74.03\%) negative results. In turn, an evaluation of uterine cervix material samples revealed $17(22.08 \%)$ positive and 60 (77.92\%) negative results.

CONCLUSIONS. The study enabled a comparison between HPV prevalence rates in urine sediment cells and in uterine cervix epithelial cells of an examined patient. The performed observations are likely to trigger a further analysis of the studied issue; however, the obtained results provide arguments for different natural histories of the infection processes.
\end{abstract}

Key words: $H O V$, recurrent cystitis, uterine cervix

\section{STRESZCZENIE}

WSTĘP. W przypadku raka urotelialnego jednym z potencjalnych czynników rakotwórczych jest wirus brodawczaka ludzkiego (HPV). Ludzki wirus brodawczaka należy do dwuniciowych wirusów DNA infekujących komórki nabłonka. Największa częstość występowania HPV stwierdzono w złośliwych procesach, które mają wpływ na szyjkę macicy, a także na okolice sromu, prącia, odbytnicy oraz gardła.

CEL PRACY. Celem podjętych badań była próba znalezienia korelacji między częstością występowania HPV w komórkach osadu moczu a złuszczonymi komórkami nabłonka szyjki macicy w grupie pacjentów z częstym, nawracającym zapaleniem pęcherza.

MATERIAŁ I METODY. Obecność wirusa HPV badano zarówno w komórkach osadu moczu, jak również w komórkach nabłonka szyjki macicy u 77 pacjentów.

WYNIKI. Analiza osadów moczowych dała łącznie dwadzieścia $(25,97 \%)$ pozytywnych i 57 (74,03\%) negatywnych wyników. Z kolei ocena próbek pochodzących z macicy wykazała 17 dodatnich wyników $(22,08 \%)$ i $60(77,92 \%)$ negatywnych wyników.

(C) National Institute of Public Health - National Institute of Hygiene / Narodowy Instytut Zdrowia Publicznego - Państwowy Zakład Higieny 
WNIOSKI. Przeprowadzone badanie umożliwiło porównanie częstości występowania wirusa HPV w komórkach osadu moczu oraz w komórkach nabłonka szyjki macicy u badanego pacjenta. Przeprowadzone obserwacje prawdopodobnie spowodują dalszą analizę badanego zagadnienia; jednak uzyskane wyniki dostarczają argumentów dla różnych naturalnych procesów infekowania.

Słowa kluczowe: $H P V$, nawracajace zapalenie pęcherza moczowego, szyjka macicy

\section{INTRODUCTION}

The juxtaposition of eleven multicentre, casecontrol studies, published by Muñoz et al. on 2003, encompassing of group of 1918 patients with cervical cancer and a group of 1928 healthy women, the study for infection with the human papillomavirus (HPV) has become a standard in cytodiagnostics (1). In the countries, where screening for HPV infection included $2 / 3$ of the female population, the morbidity and mortality rates of the patients have decreased by $80 \%$ and $70 \%$, respectively (2).

The application of molecular tests, identifying high-risk HPV DNA as a part of uterine cervix cancer prophylactics, has for 6 years been also recommended by the Polish Society of Gynaecology and the National Chamber of Laboratory Diagnosticians, as both a screening tool and an element of enhanced diagnostics (2).

The history of perception of HPV infection as an aetiopathological factor in urinary tract diseases has equally been long $(3,4)$. HPV has for some 30 years been identified as a potential carcinogenic factor in urothelial cancer cases $(5,6)$. However, up to now, no consensus has been achieved, regarding its role in the process of carcinogenesis in the urinary bladder $(7,8)$.

Discrepancies in literature data and the results of to-date's studies of the authors led to engaging in studies on the concomitant presence of HPV in urine sediment cells in comparison to its presence in desquamated epithelial cells from the uterine cervix. Some literature reports describe the presence of HPV DNA in urine sediment cells in cases of uterine cervix cancer, its incidence being higher, the higher was the stage of the disease $(9,10,11)$.

A thorough search through available medical literature databases identified only one report, dealing with the presence of HPV in DNA samples, obtained from urinary and cervical cancers (12). However, no similar publications were found on DNA samples, collected either from urinary sediments or from desquamated epithelial cells of the uterine cervix in cases of frequent, recurrent cystitis.

\section{GOAL OF STUDY}

The goal of the undertaken studies was either to confirm or to exclude any relationships between

\section{WSTĘP}

Dzięki zestawieniu jedenastu wieloośrodkowych badań o charakterze case-control, opublikowanych przez Muñoz i wsp. w 2003 r., obejmujących grupę 1918 pacjentek z rakiem szyjki macicy oraz grupę 1928 zdrowych kobiet, badanie infekcji wirusem brodawczaka ludzkiego (Human Papillomavirus - HPV) stało się standardem w cytodiagnostyce (1). W krajach, w których przebadano 2/3 populacji kobiet, uzyskano spadek zachorowalności o 80\% i umieralności pacjentek o $70 \%$ (2).

Od ponad 6 lat aplikacja molekularnych testów identyfikujących DNA HPV HR (High-risk) w profilaktyce raka szyjki macicy jest rekomendowana również przez Polskie Towarzystwo Ginekologiczne (PTG) oraz Krajową Izbę Diagnostów Laboratoryjnych (KIDL), jako element badań przesiewowych oraz diagnostyki pogłębionej (2).

Historia roli infekcji HPV jako czynnika etiopatologicznego w chorobach układu moczowego jest równie długa $(3,4)$. Od około 30 lat w przypadkach raka urotelialnego wirus HPV jest identyfikowany jako potencjalny czynnik rakotwórczy $(5,6)$. Jednakże do chwili obecnej nie uzyskano konsensu, co do jego roli w procesie nowotworzenia w obrębie pęcherza moczowego $(7,8)$.

Rozbieżności w danych literaturowych oraz dotychczasowe wyniki badań własnych zadecydowały o podjęciu badań nad jednoczasową obecnością wirusa HPV w komórkach osadu moczu w porównaniu do złuszczonych komórek nabłonkowych szyjki macicy. W literaturze istnieją doniesienia o obecności DNA wirusa HPV w komórkach osadu moczu w przypadkach raka szyjki macicy, obserwowaną tym częściej, im wyższy był stopień zaawansowania choroby $(9,10,11)$.

W dostępnym piśmiennictwie znalezioo jedno opracowanie, które dotyczyło obecności wirusa HPV w próbkach DNA uzyskanych z guza pęcherza oraz raka szyki macicy (12). Nie znaleziono natomiast podobnych opracowań dotyczących próbek DNA uzyskanych z osadu moczu oraz próbek DNA ze złuszczonych komórek nabłonkowych szyjki macicy, w przypadkach częstych nawracających zapaleń pęcherza moczowego.

\section{CEL PRACY}

Celem podjętych badań było potwierdzenie lub wykluczenie zależności pomiędzy występowaniem wirusa HPV w komórkach osadu moczu oraz złuszczo- 
HPV occurrence in urinary sediment cells and in desquamated epithelial cells of the uterine cervix in cases of frequent, recurring cystitis in women.

\section{MATERIALS AND METHODS}

Seventy-seven female patients were enrolled, meeting at least three, out of the following four criteria: the age: $35-74$ years, occupational risk (exposure to carcinogens), multiyear tobacco smoking, recurrent infections of the urinary tract (more than three documented episodes during the recent three years, pharmacologically treated). The enrolled patients were submitted to studies for HPV presence in urinary sediments and in the epithelial cells of the uterine cervix. Standard conditions were drafted for diurnal urine collection. Standard urine sample collection conditions were worked out (the first morning urine portion, a professional sterile vessel, the storage temperature $+8^{\circ} \mathrm{C}$, the storage time not above 2 hours), thus solving the most common problem with the reliability of obtained results (13). Cervical smears were taken with a sterile, disposable brush (ROVERS®EndoCERVEX-BRUSH ${ }^{\circledR}$ ) and placed in eppendorf tubes with a stabilising fluid inside.

DNA samples were isolated by means of micro-columns with ion-exchange membranes of A\&A Biotechnology. The isolated DNA was used as an input material in screening studies for HPV presence in urine sediment cells and in uterine cervix epithelial cells. The study for HPV presence was carried out with a HPV HCR-genotype-titre-FRT kit of AmpliSens, in compliance with the manufacturer's procedure. The test was based on the multiplex PCR method in real time, which enables identification of 13 oncogenic genotype of HPV with sensitivity of 1000 copies per $\mathrm{ml}$.

\section{RESULTS}

Twenty (25.97\%) positive and fifty-seven $(74.03 \%)$ negative results were obtained in urinary sediment analysis, identifying 13 various genotypes: $16,18,31,33,39,45,51,52,56,58,59,66,68$. In ten $(12.99 \%)$ cases, more than one viral genotype was simultaneously observed. In turn, an evaluation of uterine cervix material samples revealed seventeen $(22.08 \%)$ positive and sixty $(77.92 \%)$ negative results. The following genotypes were identified: $16,18,31,45$, 51,58 . In two $(2.60 \%)$ cases, several genotypes were present in one tube. Table I presents the distribution of viral genotypes. nych komórkach nabłonkowych szyjki macicy w przypadkach częstych nawracających zapaleń pęcherza moczowego u kobiet.

\section{MATERIAŁ I METODY}

Przebadano 77 pacjentek spełniających minimum trzy spośród czterech następujących kryteriów: wiek: 35 - 74 lata, ryzyko zawodowe (narażenie na kancerogeny), wieloletnie czynne palenie tytoniu, nawracające infekcje układu moczowego (powyżej trzech udokumentowanych epizodów w ostatnich trzech latach, leczone farmakologicznie). W analizowanej grupie pacjentek przeprowadzono badanie na obecność wirusa HPV w osadzie moczu oraz w komórkach nabłonkowych szyjki macicy. Opracowano standardowe warunki pozyskiwania próbki moczu (pierwsza poranna porcja moczu, profesjonalne jałowe naczynie, temperatura przechowywania $+8^{\circ} \mathrm{C}$, nie dłużej niż $2 \mathrm{~h}$ ) wychodząc naprzeciw najczęstszym problemom z rzetelnością uzyskiwanych wyników (13). Wymazy z szyjki macicy pobierano sterylną szczoteczką jednorazowego użytku ROVERS®EndoCERVEX-BRUSH ${ }^{\circledR}$, które umieszczano w probówce typu eppendorf z płynem stabilizującym.

Próbki DNA izolowano $\mathrm{z}$ wykorzystaniem mikrokolumn z membranami jono-wymiennymi firmy A\&A Biotechnology. Wyizolowane DNA stanowiło materiał do przeprowadzenia badań przesiewowych w kierunku obecności wirusa HPV w komórkach osadu moczu oraz komórkach nabłonkowych szyjki macicy. Badanie obecności HPV wykonywane było zestawem AmpliSens HPV HCR-genotype-titre-FRT zgodnie z procedurą producenta. Test opiera się na metodzie multiplex PCR w czasie rzeczywistym, który umożliwia wykrycie 13 onkogennych genotypów wirusa HPV z czułością 1000 kopii na mililitr.

\section{WYNIKI}

Ogółem otrzymano $20(25,97 \%)$ wyników pozytywnych oraz $57(74,03 \%)$ wyników negatywnych w osadzie moczu, identyfikując 13 różnych genotypów: $16,18,31,33,39,45,51,52,56,58,59,66,68$. W $10(12,99 \%)$ przypadkach zaobserwowano więcej niż jeden genotyp wirusa jednocześnie. W materiale pochodzącym z szyjki macicy otrzymano $17(22,08 \%)$ wyników pozytywnych oraz $60(77,92 \%)$ wyników negatywnych. Zidentyfikowano genotypy: 16, 18, 31, 45, 51, 58. Stwierdzono obecność kilku genotypów w jednej próbce w dwóch przypadkach $(2,60 \%)$. Rozkład genotypów wirusa przedstawiono w Tabeli I. 
Table I. The distribution of viral genotypes

Tabela I. Rozkład genotypów wirusa

\begin{tabular}{|c|c|c|}
\hline \multirow{2}{*}{ Genotype } & HPV from urine sediments & HPV from uterine cervix \\
\cline { 2 - 3 } & The number of cases & The number of cases \\
\hline 16 & $4[11.76 \%]$ & $\mathbf{5} \mathbf{2 6 . 3 1 \%}]$ \\
\hline 18 & $4[11.76 \%]$ & $3[15.79 \%]$ \\
\hline 31 & $\mathbf{5}[\mathbf{1 4 . 7 2 \%}]$ & $2[10.53 \%]$ \\
\hline 33 & $2[5.88 \%]$ & - \\
\hline 39 & $1[2.94 \%]$ & - \\
\hline 45 & $2[5.88 \%]$ & $2[10.53 \%]$ \\
\hline 51 & $\mathbf{5}[\mathbf{1 4 . 7 2 \%} \%$ & $\mathbf{5}[\mathbf{2 6 . 3 1 \%}]$ \\
\hline 52 & $2[5.88 \%]$ & - \\
\hline 56 & $3[8.82 \%]$ & - \\
\hline 58 & $3[8.82 \%]$ & $2[10.53 \%]$ \\
\hline 59 & $1[2.94 \%]$ & - \\
\hline 66 & $1[2.94 \%]$ & - \\
\hline 68 & $1[2.94 \%]$ & - \\
\hline
\end{tabular}

In the material from urine sediment cells, genotypes 31 and 51 demonstrated the higher prevalence; genotypes 16 and 18 were relatively frequent as well. Whereas in the DNA, isolated from cervical smears, genotypes 16 and 51 revealed the highest prevalence. In six cases $(7.79 \%)$, simultaneous HPV infection was identified in urine sediment cells and in cervical smears. In three, out of those cells, the same viral genotypes were found. In one case, urine sediment cells presented with five different genotypes of HPV, where one of them was also simultaneously found in cervical cells. In one case, in urine sediments, three genotypes of HPV were found, where two out of which were also present in the cervical material.

Hereby a hypothesis was postulated about a possibility of common aetiopathogenesis of both infections. In order to verify that hypothesis, the obtained material was divided into two groups: a control group, with negative results of the test for HPV presence in urine sediment and a study group, where the results were positive. Yates' chi-square test was used for the hypothesis verification and brought the results presented in Table II.
W materiale pochodzącym z komórek osadu moczu najczęstszym genotypem był genotyp 31 oraz 51, relatywnie częste były również genotypy 16 i 18 . W próbkach DNA z wymazu z szyjki macicy najczęstszym genotypem był genotyp 16 i 51 .

W sześciu przypadkach $(7,79 \%)$ wykryto jednoczesną infekcję HPV w komórkach osadu moczu oraz w wymazie z szyjki macicy. $\mathrm{W}$ trzech spośród nich wykryto te same genotypy wirusa. W 1 przypadku w komórkach $\mathrm{z}$ osadu moczu wykryto 5 różnych genotypów wirusa HPV, z czego jeden z nich występował również w komórkach szyjki macicy. W 1 przypadku w materiale $\mathrm{z}$ osadu moczu wykryto 3 genotypy wirusa, z czego 2 były również obecne w materiale pochodzącym z szyjki macicy.

Postawiono hipotezę o możliwości wspólnej etiopatogenezy obu infekcji.

W celu weryfikacji tej hipotezy podzielono materiał na dwie grupy. Pierwszą, kontrolną, w której wynik badania na obecność HPV w osadzie moczu był negatywny oraz drugą, w której wynik był pozytywny. Do sprawdzenia hipotezy zastosowano test $\mathrm{Chi}^{2} \mathrm{z}$ poprawką Yatesa (Tab. II).

Table II. Yates' chi-square test

Tabela II. Test $\mathrm{Chi}^{2} \mathrm{z}$ poprawką Yatesa

\begin{tabular}{|l|c|c|}
\hline & $\begin{array}{c}\text { Control group } \\
\text { Negative HPV from urine sediments }\end{array}$ & $\begin{array}{c}\text { Study group } \\
\text { Positive HPV from urine sediments }\end{array}$ \\
\hline Negative HPV from uterine cervix & $46[59.74 \%]$ & $14[18.18 \%]$ \\
\hline Positive HPV from uterine cervix & $11[14.29 \%]$ & $6[7.79 \%]$ \\
\hline
\end{tabular}

Chi square test: $0.4616987 ; d f=1 ; p=0.49683$

These results demonstrate no statistically significant $(\mathrm{p}>0.05)$ difference between the control group and the study group. Despite that, a group of 6 cases, with simultaneous infection in both organs, was evaluated to see the degree of convergence among various genotypes of the virus. Pearson's chi-squared test was applied for the study (Table III).
Powyższe wyniki wykazują brak istotnej statystycznie $(\mathrm{p}>0,05)$ różnicy pomiędzy grupą kontrolną a grupą badaną. Mimo to, w grupie 6 przypadków z jednoczesną infekcją w obu narządach postanowiono sprawdzić stopień zbieżności różnych genotypów wirusa. Badanie przeprowadzono stosując test $\mathrm{Chi}^{2}$ Pearsona (Tab. III). 
Table III. Pearson's chi-squared test

Tabela III. Test $\mathrm{Chi}^{2}$ Pearsona

\begin{tabular}{|c|c|c|}
\hline & HPV from urine sediments & HPV from uterine cervix \\
\hline Case $1 *$ & GT $31,58,68$ & GT 31,58 \\
\hline Case $2 *$ & GT $16,33,45,52,59$ & GT 16 \\
\hline Case 3. & GT 16 & GT 16 \\
\hline Case 4. & GT 31 & GT 51 \\
\hline Case 5. & GT 31,58 & GT 31,58 \\
\hline Case 6. & GT 18 & GT 18 \\
\hline
\end{tabular}

*Cases 1 and 2 were regarded convergent. Chi square test: $12.00000 ; d f=6 ; p=0.06197$

In the light of the made assumptions, the results of the previous analysis and $\mathrm{p}>0.05$, the obtained result was considered statistically insignificant. A detailed table, with the results of the studies in seventy-seven cases is available from the authors.

\section{DISCUSSION}

HPV is a small, circular double-stranded DNA of the virus, which occurs in epithelial cells. The virus is most often present in the uterine cervix, the vulva, the penis, the rectum and the oral part of the pharynx (14).

The urothelial (transitional cell) carcinoma of the urinary bladder demonstrates one of the highest incidence rates, especially in developing countries. It seems that the human papillomavirus is associated with the aetiology of urinary bladder tumour because of its high incidence in samples, collected from urinary bladder neoplasms in the study by MR Barghi et al. (15). The studies of $L i$ et al. (16) presented an approximately three times higher incidence of urinary bladder cancer in persons with positive results of the test for HPV presence. Kim et al. (17) demonstrated the presence of various HPV types in urinary sediment cells of thirty-five patients with urinary bladder carcinoma HPV was also identified in the urinary tract of patients with urethritis or cystitis(15). The role was not called into question in subsequent meta-analyses of reports, describing the role of HPV infection in the aetiopathogenesis of urinary bladder, however, its significance was determined to be ,moderate to certain" $(16,7,18)$. A possibility was noted of HPV infection correlation with the malignancy stage of the urinary bladder carcinoma which, with the simultaneous presence of CHEK2 gene mutation and 355T/T polymorphism of CYP1B1 gene in 131 DNA samples from tumour tissues and peripheral blood of the patients (19). However, this issue is still rather controversial, as, for example, in the study of Schmid et al. (8), no HPV presence was confirmed in any of 109 studied samples, collected from frozen tumour tissue fragments.

During the years 2014-2015, while implementing the "Programme of early infections with human
Otrzymany wynik uznano za nieistotny statystycznie $(p>0,05)$. Szczegółowa tabela uwzględniająca wyniki badań w 77 przypadkach do wglądu u autorów artykułu.

\section{DYSKUSJA}

HPV jest małym, kolistym, dwuniciowym wirusem DNA, który występuje w komórkach nabłonkowych. Najczęstszymi lokalizacjami obecności wirusa jest szyjka macicy, srom, penis, odbyt i część ustna gardła (14).

Jednym z najczęstszych nowotworów złośliwych, zwłaszcza w krajach rozwijających się, jest rak urotelialny (przejściowokomórkowy) pęcherza moczowego. Wydaje się, że ludzki wirus brodawczaka jest związany z etiologią guza pęcherza moczowego ze względu na jego wysoką częstość występowania w próbkach uzyskanych z nowotworów pęcherza moczowego w badaniu MR Barghi i wsp. (15).

W badaniach $L i$ i wsp. (16) wykazano około 3-krotnie częstsze występowanie raka pęcherza moczowego u osób, u których wynik testu w kierunku obecności wirusa HPV był pozytywny. Kim i wsp. (17) u 35 pacjentów z rakiem pęcherza moczowego wykazali obecność różnych typów wirusa HPV w komórkach z osadu moczu (15). Zidentyfikowano również obecność wirusa HPV w drogach moczowych u pacjentek z zapaleniem cewki moczowej i zapaleniem pęcherza moczowego. W kolejnych meta-analizach doniesień o roli infekcji HPV w etiopatogenezie raka pęcherza nie zakwestionowano tej roli, jednakże jej znaczenie określono jako moderate to certain $(16,7,18)$. Odnotowano możliwość korelacji infekcji HPV ze stopniem złośliwości raka pęcherza moczowego, przy jednoczesnej obecności mutacji genu CHEK2 oraz polimorfizmu 355T/T genu CYP1B1 w 131 próbkach DNA pochodzących z tkanki guza i krwi obwodowej pacjentów (19). Jednakże temat ten jest ciągle kontrowersyjny, gdyż w badaniu Schmid i wsp. (8) nie stwierdzono obecności wirusa HPV w żadnej ze 109 badanych próbek pochodzących z zamrożonych fragmentów tkanki guza.

W latach 2014-2015 realizując program zdrowotny „Program wczesnego wykrywania zakażeń wiru- 
HPV", financed by the Local Government of the Lodz Voivodeship, 409 female patients were examined for HPV infection in the uterine cervix. Eightyseven $(21.27 \%)$ of positive results were recorded (unpublished data). Comparing the above results to the analysed 77 cases, one may say that in cases of frequent, recurrent cystitis in women, the percent of HPV infections in the uterine cervix is not statistically different form the incidence among the persons who fulfilled the inclusion criteria in the above-mentioned healthcare programme (Chi square: $0.0251 ; \mathrm{df}=1 ; \mathrm{p}$ $=0.874216$ ).

In the presented clinical material, the number of cases with convergent distribution of HPV genotypes, both in urine sediment and in cervical material cells, does not allow for confirmation of the hypothesis about the common aetiopathogenesis of both infections. The number of cases, in which HPV was found in one organ only and the case, in which different genotypes of the virus were identified in both organs, speak in favour of different natural histories of those infections.

\section{CONCLUSIONS}

An attempt was undertaken to evaluate the presence and distribution of different HPV genotypes in a group of patients with recurrent inflammations of the urinary tract. HPV genotypes were searched in urinary sediment cells and their incidence was compared with the incidence of HPV genotypes in desquamated epithelial cells of the uterine cervix. No statistically significant convergence was noted in the distribution of HPV genotypes between the infection presence in urine sediment cells vs. the infection in DNA samples, acquired from the desquamated epithelial cells of the uterine cervix.

\section{REFERENCES}

1. Sikorski M. Zakażenia HPV - Współczesne poglądy i praktyka. Poznań: Termedia Wydawnictwa Medyczne; 2008: 15-18.

2. Wytyczne dotyczące aplikacji testów molekularnych identyfikujących DNA HPV HR w profilaktyce raka szyjki macicy. Stanowisko ekspertów PTG I KIDL. Ginekol Pol. 5/2013;84:395-399.

3. Gissmann L, zur Hausen H. Partial characterization of viral DNA from human genital warts (Condylomata acuminata).Int J Cancer. 1980;15;25(5):605-9.

4. Melchers WJG, Schift R, Stolz E et al. Human Papillomavirus Detection in Urine Sampes from Male Patients by the Polymerase Chain Reaction. JCM. 1989;8:17111714.

5. Koss LG, Sherman AB, Eppich E. Image analysis and DNA content of urothelial cells infected with human polyomavirus. Anal Quant Cytol. 1984;6:89-94. sem brodawczaka ludzkiego HPV" finansowany przez Samorząd Województwa Łódzkiego przepadano 409 pacjentek pod kątem obecności infekcji HPV w szyjce macicy. Uzyskano 87 (21,27\%) wyników pozytywnych (dane niepublikowane). Porównując powyższe wyniki do analizowanych 77 przypadków, można stwierdzić, że w przypadkach częstych, nawracających zapaleń pęcherza moczowego u kobiet odsetek infekcji HPV w szyjce macicy nie jest statystycznie różny od częstości wśród osób, które spełniły kryteria włączenia do programu zdrowotnego (Chi-kwadrat: 0,0251; $\mathrm{df}=$ $1 ; p=0,874216$ ).

W prezentowanym materiale klinicznym liczba przypadków zbieżnej dystrybucji genotypów wirusa HPV w komórkach z osadu moczu oraz komórkach pochodzących z szyjki macicy nie pozwala na potwierdzenie hipotezy o wspólnej etiopatogenezie obu infekcji. Liczba przypadków, w których obecność wirusa HPV stwierdzono tylko w jednym $\mathrm{z}$ narządów oraz przypadek, w którym w obu narządach, zidentyfikowano różne genotypy wirusa przemawiają za różną historią naturalną tych infekcji.

\section{WNIOSKI}

Podjęto próbę oceny obecności i dystrybucji różnych genotypów wirusa HPV w grupie pacjentek $\mathrm{z}$ nawrotowym zapaleniem dróg moczowych w komórkach osadu moczu w odniesieniu do złuszczonych komórek nabłonkowych szyjki macicy. Nie odnotowano statystycznie znamiennej zbieżności dystrybucji genotypów wirusa HPV między obecnością infekcji w komórkach osadu moczu w porównaniu do infekcji w próbkach DNA pozyskanych ze złuszczonych komórek nabłonkowych szyjki macicy.

6. Kitamura T, Yogo Y, Doi N, et al. Bladder carcinoma in situ which harbored human papilloma virus. A case report. Nihon Hinyokika Gakkai zasshi. The japanese journal of urology. 1989;80:1224-1227.

7. Jimenez-Pacheco A, Exposito-Ruiz M, Arrabal-Polo MA, et al. Meta-analysis of studies analyzing the role of human papillomavirus in the development of bladder carcinoma. Korean J Urol. 2012;53:240-247.

8. Schmid SC, Thümer L, et al. Human papilloma virus is not detectable in samples of urothelial bladder cancer in a central European population: a prospective translational study. Infect Agent Cancer. 2015;10:31.

9. Prado PYY, Veitia D, Ferreiro MC, et al. Molecular detection of human papillomavirus in urine and cytologyc feminine samples. MOJ Tumor Res. 2018;1(3):113-117.

10. Song E-S, Lee HJ, Hwang TS. Clinical Efficacy of Human Papillomavirus DNA Denection in Urine from Patients with Various Cervical Lesions. J Korean Med Sci. 2007;22:99-104. 
11. Vorsters A, Van Keer S, Biesmans S, et al. Long-Term Follow-up of HPV Infection Using Urine and Cervical Quantitative HPV DNA Testing. IJMS. 2016;17(5):750.

12. Shigehara K, Kawaguchi S, Sasagawa T, et al. Etiological correlation of human papillomavirus infection in the development of female bladder tumor. APMIS. 2013;121:1169-1176.

13. Vorsters A, Micalessi I, Bilcke J, et al. Detection of human papillomavirus DNA in urine. A review of the literature. Eur J Clin Microbiol Infect Dis. 2012;31:627640.

14. zur Hausen H. Papillomaviruses in the causation of human cancers - a brief historical account. Virol. 2009;384:260-265.

15. Barghi MR, Hajimohammadmehdiarbab A, Moghaddam SM, et al. Correlation between human papillomavirus infection and bladder transitional cell carcinoma. BMC Infect Dis. 2005;5:102.

16. Li N, Yang L, Zhang Y, et al. Human papillomavirus infection and bladder cancer risk: a meta-analysis. J Infect Dis. 2011;204:217-223.

17. Kim SH, Joung JY, Chung J, et al. Detection of human papillomavirus infection and p16 immunohistochemistry expression in bladder cancer with squamous differentiation. PLoS One. 2014;9:e93525.
18. Shigehara K, Sasagawa T, Namiki M. Human papillomavirus infection and pathogenesis in urothelial cells: a mini-review. J Infect Chemother. 2014;20:741-747.

19. Banaszkiewicz M, Constantinou M, Pietrusiński M, et al. Concomitance of oncogenic HPV types, CHEK2 gene mutations, and CYP1B1 gene polymorphism as an increased risk factor for malignancy. Cent European J Urol. 2013;66:23-29.

Received: 2.10.2018

Accepted for publication: 8.02.2019

Otrzymano: 2.10.2018 r.

Zaakceptowano do publikacji: 8.02.2019 r.

\section{Correspondence address:}

Adres do korespondencji:

Magdalena Owczarek

P.P.H.U. Genos s.c.

Strońsko 20A

98-161 Zapolice

magdalenaowczarek@genos.com.pl 